\title{
Bronchogenic Squamous Cell Carcinoma Mass with Central Photopenia on FDG-PET Scan
}

\author{
Vikram Sahni, MD; Sebnem Guvenc-Tuncturk, MD; Harman S. Paintal, MD; and Ware G. Kuschner, MD
}

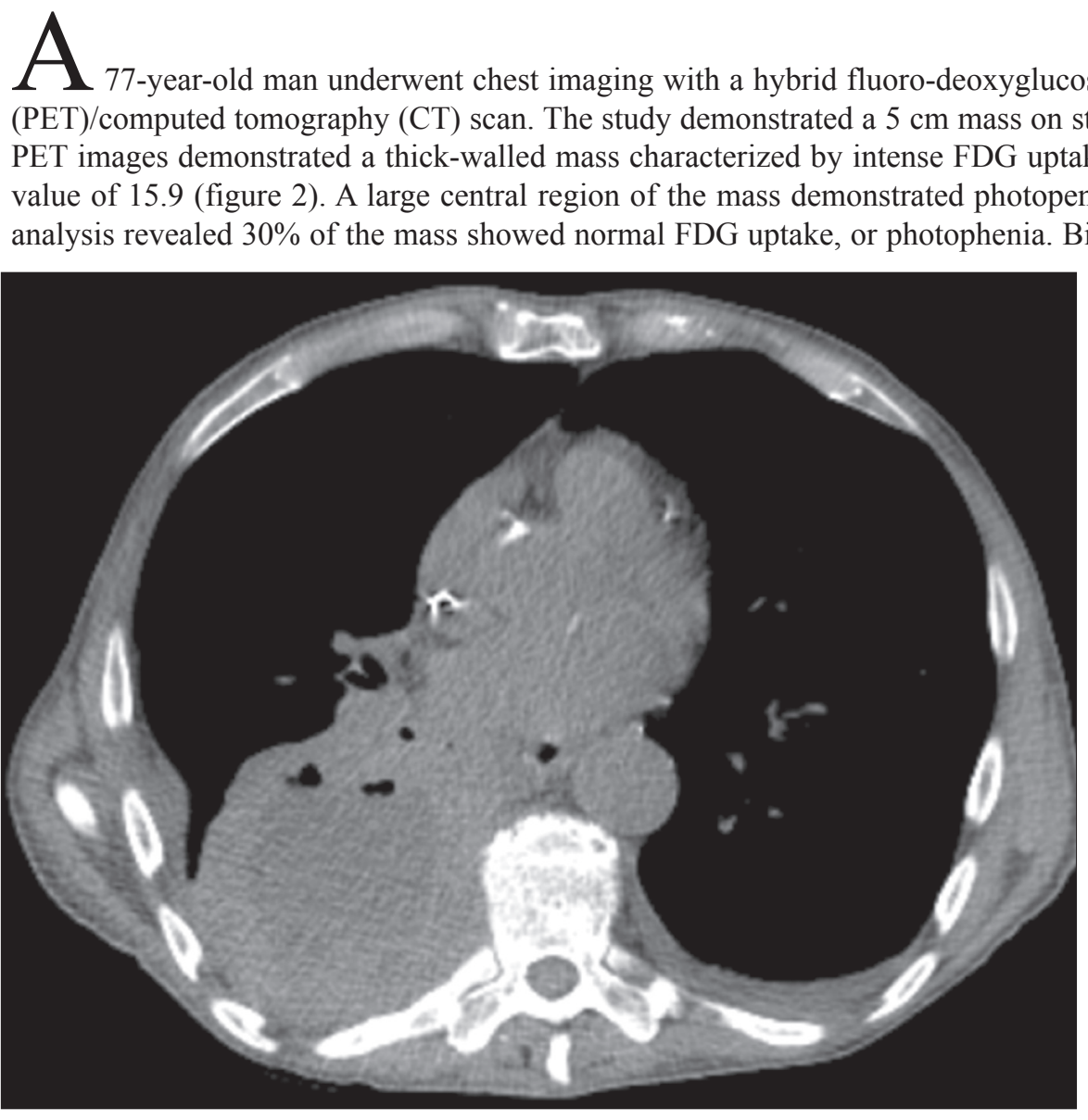

Figure 1. Thoracic computed tomography image showing right lower lobe mass. \begin{abstract}
carcinoma The findings were consistent with carcinoma that had outgrown its vascular supply resulting in central tumor necrosis.
\end{abstract}

Central necrosis is most commonly observed in primary bronchogenic carcinomas of squamous cell origin, with one series reporting squamous cell origin in $82 \%$ of cases of necrotizing lung cancer. ${ }^{1}$ In an analysis of patterns of FDG uptake in lung cancer based on histologic classification, both large cell and squamous cell carcinomas were significantly more likely to demonstrate central cavitation compared with adenocarcinoma. $^{2}$

The pathogenesis of cavitary malignancies has not been fully elucidated. It has been postulated that cavity formation in tumors is a consequence of rapid tumor growth which exceeds the supporting blood supply resulting in tumor necrosis and
Corresponding Author:

Ware G. Kuschner, MD

US Department of Veterans Affairs

Palo Alto Health Care System

380 I Miranda Avenue

Pulmonary Section, Mail Code: III P

Palo Alto, CA 94304 USA

Tel: 650-493-5000, ext. 63544

Fax: 650-852-3276

Email: kuschner@stanford.edu
Keywords: Cancer; Cavitation; FDG-PET

Received: April 7, 2011

Revised: July I8, 2011

Accepted: July 20, 2011

doi: $10.3121 / \mathrm{cmr} .2011 .1013$

The Aperture, like the opening in the lens of a microscope that allows light to pass through, is a forum for art, humor, and images that provides a portal for new or different views of medicine and research. 


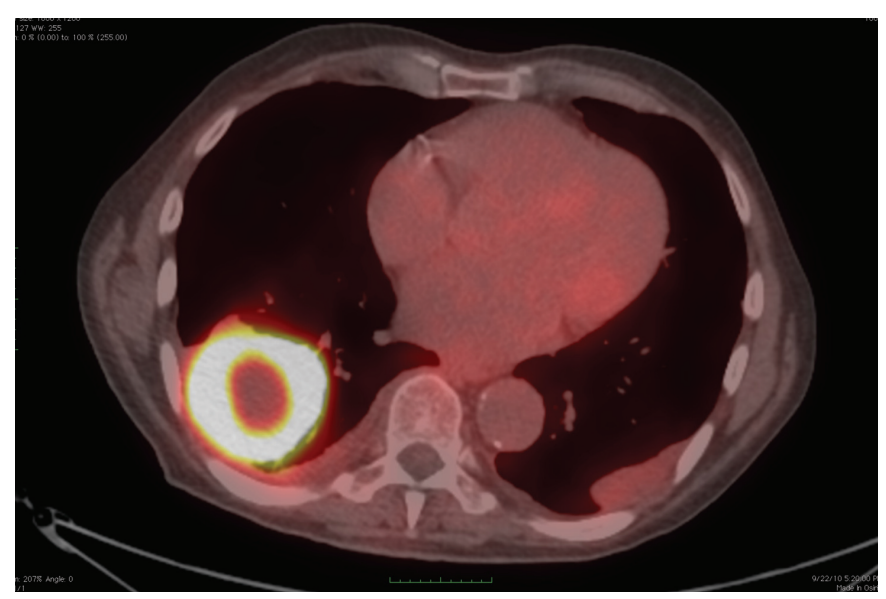

Figure 2. Hybrid fluoro-deoxyglucose (FDG) positron emission tomography/computed tomography image showing a thick-walled mass characterized by FDG uptake with a maximum standardized uptake value of 15.9 in the wall of the mass and central photopenia, consistent with cavitation and central necrosis.

cavitation. ${ }^{3}$ This hypothesis is supported by reports that have shown tumor-associated vasculature inhibition by antiangiogenesis agents causing central necrosis and cavity formation in patients with squamous cell carcinoma of the lung. ${ }^{4,5}$

The development of cavitation may have clinically significant consequences. Cavitating lung tumors may initially simulate an infectious process leading to delayed work up, late diagnosis, and presentation with advanced disease. In previous analyses of patient populations with heterogeneous stages of bronchogenic carcinoma, no difference in survival or response to therapy was found between lung cancers with cavitation and those without cavitation. ${ }^{1,6}$ However, in a more recent analysis of 72 patients with stage I non-small cell lung cancer, cavitation within the primary tumor was associated with significantly shorter disease-free survival time and overall survival time. ${ }^{7}$ In this analysis, cavitary lesions were significantly more common in squamous cell carcinomas than in adenocarcinomas and in epidermal growth factor receptor (EGFR)-overexpressing tumors than in tumors that did not overexpress EGFR. Accordingly, the presence of cavitation may have therapeutic implications in helping identify patients likely to benefit from targeted treatment with an anti-EGFR agent.

In summary, clinicians should be aware that large bronchogenic carcinomas may develop central cavitation and necrosis, likely resulting from compromised vascular supply, resulting in central photopenia on FDG-PET imaging. This finding may have prognostic and therapeutic implications.

\section{References}

1. Mouroux J, Padovani B, Elkaïm D, Richelme H. Should cavitated bronchopulmonary cancers be considered a separate entity? Ann Thorac Surg 1996;61:530-532.

2. Wong CY, Nuñez R, Bohdiewicz P, Welsh RJ, Chmielewski GW, Ravikrishnan KP, Hill JC, Pursel SE, Fink-Bennett D, Balon H, Dickinson C, Dworkin HJ. Patterns of abnormal FDG uptake by various histological types of non-small cell lung cancer at initial staging by PET. Eur J Nucl Med 2001;28:1702-1705.

3. Mooi WJ. Common lung cancers. In: Hasleton PS, ed. Spencer's pathology of the lung. 5th ed. New York, NY: McGraw-Hill; 1996. 1009-1064.

4. Marom EM, Martinez CH, Truong MT, Lei X, Sabloff BS, Munden RF, Gladish GW, Herbst RS, Morice RC, Stewart DJ, Jimenez CA, Blumenschein GR Jr, Onn A. Tumor cavitation during therapy with antiangiogenesis agents in patients with lung cancer. J Thorac Oncol 2008;3:351-357.

5. Johnson DH, Fehrenbacher L, Novotny WF, Herbst RS, Nemunaitis JJ, Jablons DM, Langer CJ, DeVore RF 3rd, Gaudreault J, Damico LA, Holmgren E, Kabbinavar F. Randomized phase II trial comparing bevacizumab plus carboplatin and paclitaxel with carboplatin and paclitaxel alone in previously untreated locally advanced or metastatic non-small-cell lung cancer. J Clin Oncol 2004;22:2184-2191.

6. Pentheroudakis G, Kostadima L, Fountzilas G, KalogeraFountzila A, Klouvas G, Kalofonos C, Pavlidis N. Cavitating squamous cell lung carcinoma-distinct entity or not? Analysis of radiologic, histologic, and clinical features. Lung Cancer 2004; 45:349-355.

7. Onn A, Choe DH, Herbst RS, Correa AM, Munden RF, Truong MT, Vaporciyan AA, Isobe T, Gilcrease MZ, Marom EM. Tumor cavitation in stage I non-small cell lung cancer: epidermal growth factor receptor expression and prediction of poor outcome. Radiology 2005;237:342-347.

\section{Author Affiliations}

Vikram Sahni, MD*,+; Sebnem Guvenc-Tuncturk, MD*,+; Harman S. Paintal, MD*, ; Ware G. Kuschner, MD*,

\author{
*Medical Service, Pulmonary Section; United States \\ Department of Veterans Affairs Palo Alto Health Care \\ System, Palo Alto, CA \\ Division of Pulmonary and Critical Care Medicine, \\ Stanford University School of Medicine, Palo Alto, CA
}

